\title{
Natural Regeneration of Marker Species of the Tropical Dense Humid Ecosystems in the Loukaya Peri-Urban Forest, Brazzaville-Congo
}

\author{
Victor Kimpouni ${ }^{1,2^{*}}{ }^{\oplus}$, Jean de Dieu Nzila1,2, Oracle Clément Tondo Bafouiri Ntsoni ${ }^{1}$, \\ Ghislain Bileri-Bakala ${ }^{2}$, Josérald Chaîph Mamboueni², Charmes Maïdet Massamba-Makanda ${ }^{2}$
}

${ }^{1}$ École Normale Supérieure, Université Marien Ngouabi, Brazzaville, Congo

${ }^{2}$ Institut National de Recherche Forestière (IRF), Brazzaville, Congo

Email: *vkimpouni@yahoo.com

How to cite this paper: Kimpouni, V., de Dieu Nzila, J., Ntsoni, O.C.T.B., Bileri-Bakala, G., Mamboueni, J.C. and Massamba-Makanda, C.M. (2020) Natural Regeneration of Marker Species of the Tropical Dense Humid Ecosystems in the Loukaya Peri-Urban Forest, Brazzaville-Congo. Open Journal of Ecology, 10, 664-687. https://doi.org/10.4236/oje.2020.1010041

Received: September 16, 2020

Accepted: October 27, 2020

Published: October 30, 2020

Copyright $\odot 2020$ by author(s) and Scientific Research Publishing Inc. This work is licensed under the Creative Commons Attribution International License (CC BY 4.0).

http://creativecommons.org/licenses/by/4.0/ (c) (i) Open Access

\begin{abstract}
The study aimed at evaluating the natural regeneration of some characteristic species in the Loukaya peri-urban forest was carried out in Brazzaville, over three surveys of one hectare each. The botanical inventory of the 23 species monitored covers the subjects of $2 \leq \mathrm{d}^{0.20}<10 \mathrm{~cm}$ and $\mathrm{d}^{1.30} \geq 10 \mathrm{~cm}$. The study shows 1255 individuals of which $68.27 \%$ are $2 \leq \mathrm{d}^{0.20}<10 \mathrm{~cm}$. While being tropophilic and mesophilic, this ecosystem is pauciflorous and paucispecific. The phytoecological data show that this formation, which is a link in the African dense humid forest, presents values far below those known elsewhere; while being faithful to the forests of the Cataractes Plateau. As for the rate of natural regeneration, this index is greater than or equal to 100 for $69.56 \%$ of the taxa. Sarcochores and heliophytes are the taxa that best support this natural regeneration. This high rate of regeneration would be correlated with the high level of anthropization, whose large canopy gaps are accompanied by a flow of light conducive to the installation of seedlings.
\end{abstract}

\section{Keywords}

Congo, Biodiversity Index, Peri-Urban Forest, Phytoecology, Natural Regeneration

\section{Introduction}

The management of urban and peri-urban forest ecosystems has always been one of the major problems of municipal authorities in Africa in general and in 
Congo in particular [1]. Forests provide communities with several tangible and intangible assets known as ecosystem goods and services [2] [3] [4] [5] [6]. This range of products represents a source of socio-cultural and economic goods (handicrafts, food, water, fuelwood, service and timber, traditional medicine, agricultural land...), and much more subtle ecological and environmental functions that enhance life, such as climate regulation, carbon sequestration, maintenance of air quality... [7]-[12]. The exploitation of goods that are part of supply services (handicrafts, food, fuelwood, timber for services and labor, traditional medicine), which is most often unsustainable, leads to the depletion of resources and the progressive, even irreversible, impoverishment of ecosystems [13].

The expansion of the city of Brazzaville in recent years, under demographic pressure and anarchic urbanization, has resulted in the integration of formerly suburban territories into the urban fabric [14]. This operation leads to the degradation and sometimes disappearance of peri-urban ecosystems, notwithstanding the direct (physiological, socio-cultural, economic, aesthetic, scientific, educational) and indirect (climatic, environmental) benefits resulting from their maintenance [15] [16]. Anthropic action, which is devastating for forest ecosystems, affects the extent of the original area, the floristic composition and impacts the 3 degrees of biodiversity $(\alpha, \beta, \gamma)$. The forest islands resulting from the degradation of the Patte d'Oie in Brazzaville, the peri-urban forest of Djoumouna whose area declined by $49.41 \%$ between 1998 and 2017 and the disappearance of the Tsiémé, Glaciaire, Corniche and Ravine forests in Chad are a perfect illustration of this [10] [17] [18] [19].

Tropical forest ecosystems are recognized as sufficiently resilient to regenerate after disturbance [8] [9] [20]. Only sustained and/or prolonged logging, causing a break in forest succession, would be likely to divert the dynamics of its trajectory towards the establishment of secondary formations [21]. Their resilience capacity is such that they are capable of recovering an architectural structure very close to the primary forest only a few years after agricultural land is set aside, beyond the fact that the floristic parameters are other than the original ones [9].

In view of the socio-cultural, economic and environmental importance of urban and peri-urban forests, several studies are being carried out on these ecosystems, without delving into the issues of natural regeneration and the dynamics of reconstitution. The themes treated preferentially are ethnobotany [22] [23] [24] and quantitative ecology stricto sensu [1] [10] [16] [18]. The objective of this study is to highlight the state of natural regeneration of urban and peri-urban forests, through the monitoring of some species' characteristic of the Loukaya woody formation.

\section{Material and Methods}

\subsection{Presentation of the Study Area}

The peri-urban forest of the Loukaya River is located south-west of Brazzaville 
between $4^{\circ} 21^{\prime} 21.6^{\prime \prime}-4^{\circ} 21^{\prime} 36^{\prime \prime}$ south latitude and between $15^{\circ} 6^{\prime} 21.6^{\prime \prime}$ - 15 $5^{\circ} 32.4^{\prime \prime}$ east longitude (Figure 1). Evolving in a densely populated area, the Loukaya Forest is bounded to the north by the village Makana 1, to the northeast by Nganga-Lingolo about $4.90 \mathrm{~km}$ from the tollgate, to the east by the village Djoumouna, to the south by the village Bissinza, to the southwest by the village Bouanissa, and to the west by the village Makana 2 .

The climate of the locality is Bas-Congolese of the Sudano-Guinean type [25] [26] whose specificities are: an average annual temperature of about $25^{\circ} \mathrm{C}$, a low annual thermal amplitude of $5^{\circ} \mathrm{C}$ to $6^{\circ} \mathrm{C}$ (Figure 2); average annual rainfall of 1200 to $1400 \mathrm{~mm}$ [27]. The rains that punctuate the alternation of the seasons begin very weakly at the end of September and settle from October to May, with a very marked slowdown from January to February. The hottest and wettest months are usually March, April and November. On the other hand, the months of June to September are the driest, while July and August are the coolest [26] [28]. Relative humidity, always above $70 \%$, is vital for the flora, especially in the dry season. The annual hygrometric amplitude is low and the daily average varies from $33 \%$ in the rainy season to $46 \%$ in the dry season [27] [28]. Evaporation varies in the opposite direction of atmospheric humidity (Figure 2) and presents a relative minimum in June and an absolute maximum in August and September [27]. In relation to the seasons, the relative minimum occurs at the turn of the rainy and dry seasons, while the absolute maximum is observed in the last phase of the dry season. In sum, evaporation is moderately low and stable in the rainy season follows the opposite trend of rainfall in January - February; and rises sharply in the dry season.

According to Denis [25], the geological substratum is composed of sedimentary formations of Cenozoic (Tertiary) age, of sandstone nature that form the

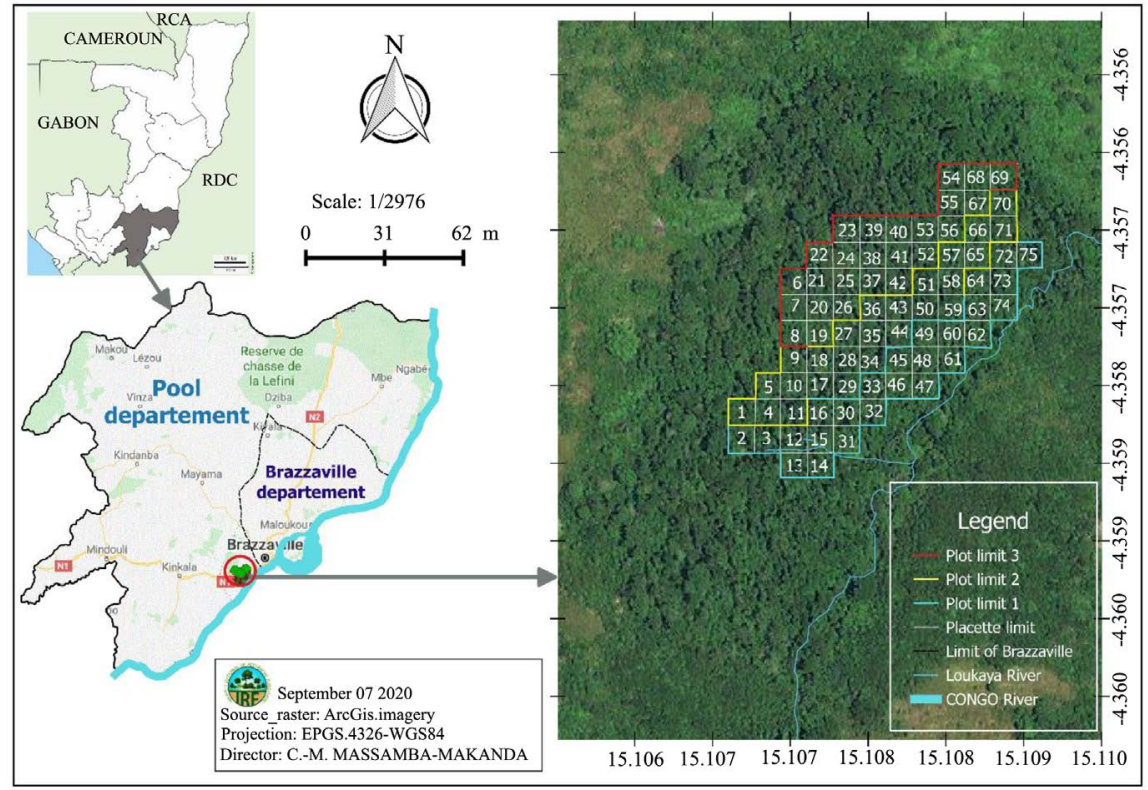

Figure 1. Location of the Loukaya peri-urban forest. 


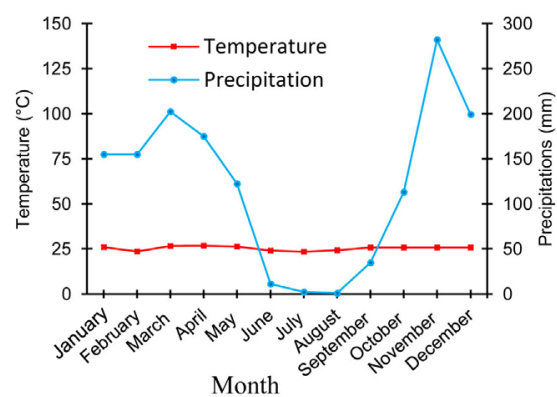

(a)

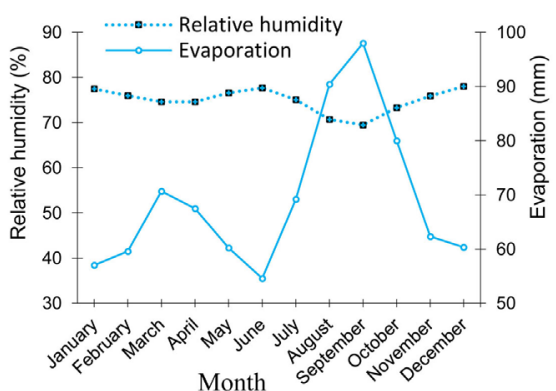

(b)

Figure 2. Climate parameters of the study area (2000-2018 period, source ANAC). Legend: Ombrothermal curve (a); Relative humidity and evaporation curves (b).

Inkisi sandstone series. According to the authors, this bedrock either is from the Upper Kalahari or is the result of in situ alteration of the schistose sandstone system. This system is composed of two superimposed sets, namely 1) the upper layers known as sandy siltstones, which constitute a large set of ochre-coloured aeolian sandy siltstones that occupy the upper parts of the plateaux. These highly mobile silts have given rise to major reworking, both in situ and by dragging into the valleys; 2) the lower layers known as polymorphic sandstones, which are represented by soft, yellow, white or pink sandstones, with fine and regular grain, without marked stratification.

The soils belong to the class of highly desaturated ferrallitic yellow psamite soils on Batékés sandstones of plateau slopes and hills, as well as hydromorphic soils [25]. From the physical and chemical point of view, highly desaturated ferrallitic soils are acidic soils $(\mathrm{pH}<5.5)$, with a low sum of exchangeable bases (1 meq $/ 100 \mathrm{~g}$ ) and a low saturation rate (less than $20 \%$ ) of the absorbent complex.

The vegetation in the study area is a forest-savanna mosaic [29] [30]. Forests are established on various topographical positions, hilltops, mainly where there are sandy overburden, slopes, valleys, and often swampy shallows. The forest in the valley bottoms takes the form of narrow galleries and is generally much degraded. In addition to these formations, larger massifs, located along the Congo River, generate ombrophilous Gilbertiodendron dewevrei or more often mesophilic semi-caducifolia formations.

\subsection{Materials}

The plant material consists of the trees of $\mathrm{d}^{1.30} \geq 10 \mathrm{~cm}$ of the selected species and their regenerative cohort of diameter between $2 \leq \mathrm{d}^{0.20}<10 \mathrm{~cm}$, at $20 \mathrm{~cm}$ from the ground. The selected individuals in the regenerative cohort are at least $30 \mathrm{~cm}$ in height because below this value the survival of individuals is very random [31]. The selection of regeneration species is based on the fact that they are characteristic of the dense tropical rainforests of Central Africa. The taxonomic ordination adopted is APG IV [32] and the nomenclature followed is that of Lebrun and Stork [33]. The parameters monitored are types of diaspora and affinity to light. 
The types of diasporas recognized follow the classification of [34] taken up by [10] [16] [23] [24] [35] [36]:

- Ballochores (Ballo): diaspores expelled by the plant itself;

- Barochores (Baro): non-fleshy, heavy diasporas;

- Pterochores (Ptero): diasporas with aliform appendages;

- Sarcochores (Sarco): diasporas totally or partially fleshy.

The type of affinity to light described by Lebrun [35] [37] and taken up by

[36] reveals the groups of:

- heliophytes (Heliophytes), plants that enjoy full sunlight. In this group, one finds mainly plants from well-lit grassy groups, trees and lianas from the upper tree dome;

- hemi-heliophytes (Hemi-Helio), plants of the intermediate strata of the forests, trees of the dome which regenerate in undergrowth and can live for a certain time in diffuse light. These plants receive on average $50 \%$ to $75 \%$ of the total illumination [38];

- hemi-sciaphytes (Hemi-Scia), plants of the forest undergrowth that still receive 5 to $50 \%$ of relative illumination [38];

- sciaphytes (Scia), plants of the lower and humigenous strata of forests in general. The illumination received is limited to $1 \%$ to $5 \%$ of the total light [38].

\subsection{Sampling Device}

The research system is based on three adjacent surveys of 1 ha, each unit consisting of 25 plots of $400 \mathrm{~m}^{2}$ (Figure 3 ).

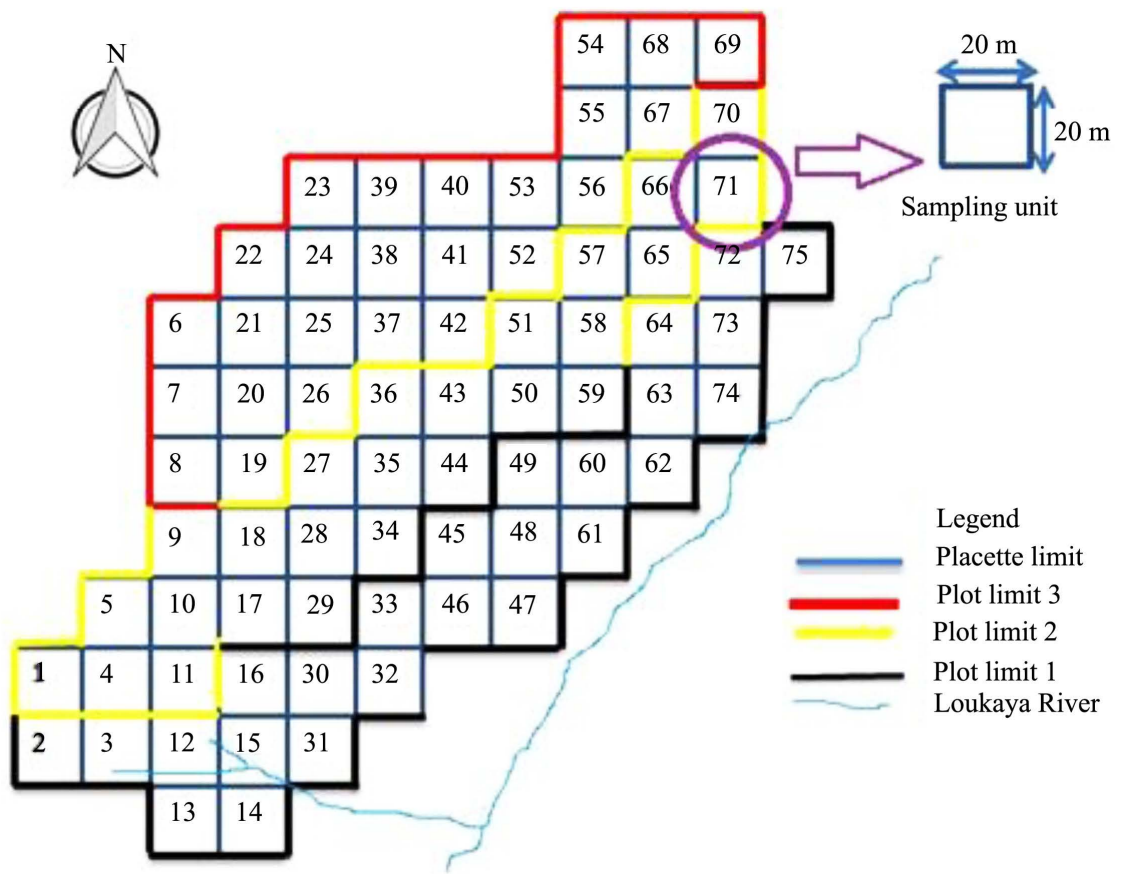

Figure 3. Floristic sampling device. 


\subsection{Methods of Study}

For dense tropical rainforests, several methods are used to study natural regeneration. For this study, the full floristic inventory coupling the count of all individuals of selected species from the regenerative cohort $\left(2 \leq \mathrm{d}^{0.20}<10 \mathrm{~cm}\right)$ to trees of $\mathrm{d}^{1.30} \geq 10 \mathrm{~cm}$ is carried out over the entire study area [10] [39]. This method, which provides a better understanding of the notion of natural regeneration, has the advantage of making data reliable and modelling.

\subsubsection{Floristic Inventory}

Plot by plot and systematically, all individuals of $2 \leq \mathrm{d}^{0.20}<10 \mathrm{~cm}[40]$ and $\mathrm{d}^{1.30} \geq$ $10 \mathrm{~cm} \mathrm{[41]} \mathrm{of} \mathrm{the} \mathrm{monitored} \mathrm{species} \mathrm{are} \mathrm{identified,} \mathrm{counted} \mathrm{and} \mathrm{measured.} \mathrm{The}$ diameter of the individuals of the regenerative cohort was measured with the caliper, while the $\mathrm{d}^{1.30} \geq 10 \mathrm{~cm}$ were measured with a metric tape measure. The height of the woody trees was measured with 1) a $1.50 \mathrm{~m}$ wooden ruler and a 5 $\mathrm{m}$ folding tape measure for small trees and 2) at the vertex for large trees. The height data of the individuals allow an appreciation of the vertical structure of the stand, especially of the selected species. The vertical stratification is based on the biological typology of Raunkiaer [42] adapted to tropical forests by Lebrun [37]. The classification adopted for the Loukaya forest is in line with work carried out in the region [43] [44] [45] and whose strata are defined as follows.

\begin{tabular}{ccc}
\hline Stratum & Limit & Biological forms \\
\hline I & $0.25-2 \mathrm{~m}$ & Nanophanerophytes \\
II & $2-10 \mathrm{~m}$ & Microphanerophytes \\
III & $10-30 \mathrm{~m}$ & Mesophanerophytes \\
IV & $>30 \mathrm{~m}$ & Megaphanerophytes \\
\hline
\end{tabular}

\subsubsection{Expression of Results}

1) The species scarcity index [46]:

$$
R i=\left[1-\frac{n i}{N}\right] \times 100
$$

with $n i=$ the number of plots where the species is encountered and $N=$ the total number of plots inventoried.

Species with a depletion index of less than $80 \%$ are considered preferential, very frequent and abundant in the study areas. Those whose rarefaction index is higher than $80 \%$ are said to be rare and therefore highly endangered in the locality.

2) The similarity coefficients of Jaccard $(S)$ and Sørensen $(K)$ [47]. The Jaccard and Sørensen similarity coefficients are distinguished by the fact that Jaccard gives the same value to presence as to absence, while Sørensen gives a double advantage to presence. In the latter case, presence is more informative than absence.

$$
S(\%)=\frac{C}{A+B-C} \times 100
$$




$$
K(\%)=\frac{2 C}{A+B} \times 100
$$

where " $A$ " is the number of species in the $1^{\text {st }}$ survey; " $B$ " the number of species in the $2^{\text {nd }}$ survey; and “ $C$ " the number of species common to both surveys.

3) Diaspora types, light affinity and structural parameters are expressed as raw and weighted spectra, according to the two formulas given as examples:

$$
S B(\%)=\frac{A}{B} \times 100
$$

where " $A$ " is the species number by diasporas type; and " $B$ " the total species number

$$
S P(\%)=\frac{A}{B} \times 100
$$

where " $A$ " is the trees number by diaporas type; and " $B$ " the total trees number.

4) Density is the number of woody individuals per hectare;

$$
D=\frac{A}{B}
$$

where " $A$ " is the total trees number (or taxa) per plot; and " $B$ " the total plot area (ha)

5) Woody frequency $(F)$;

$$
F=\frac{A}{B} \times 100
$$

where " $A$ " is the plots number where taxon is recorded; and " $B$ " the total plots number

6) The basal area $\left(\mathrm{m}^{2} \cdot \mathrm{ha}^{-1}\right)$ indicates the spatial areas occupied by all trunk sections;

$$
S=\sum \frac{\pi D i^{2}}{4}
$$

7) The natural regeneration rate (NR), according to the Rothe scale [48] and taken up by Ramananjatovo [31], is used to judge the regeneration capacity of a species or a habitat.

$$
T R=\frac{A}{B} \times 100
$$

where " $A$ " is the regeneration individuals number; and " $B$ " the other individuals' regeneration number. Regeneration is: difficult if $T R<100 \%$; good for $100 \leq T R$ $<1000 \%$; very good when $T R \geq 1000 \%$.

8) The dispersion index $(I)$ is the ratio of the variance to the mean of the counts. This index provides information on the type of spatial distribution of the units counted. A dispersion: regular for a value significantly less than 1; random for an index equal or close to 1; and aggregated in other cases [49] [50].

$$
I=S^{2} / \bar{X}
$$

The values of the dispersion index $(I)$ were subjected to the chi-square test $\left(\chi^{2}\right)$ 
for $\alpha=5 \%$, in order to verify if they are significantly different from 1 (random dispersion).

$$
\chi^{2}(d f=Q-1)=(Q-1) S^{2} / \bar{X}
$$

with $Q$ the number of plots, $S^{2}$ and $\bar{X}$ respectively the variance and the mean of the number of trees per subplot.

The statistical processing was done with " $R$, Past and Excel software". The results are subjected to the analysis of variance (ANOVA) using $\mathrm{R}$ software. The mean values of the results of the biodiversity indices and structural parameters will be compared and their significant differences will be evaluated at the probability threshold $\mathrm{p}<0.05$.

\section{Results}

\subsection{Taxonomic and Floristic Data}

The inventory shows 23 species corresponding to 21 genera grouped in $13 \mathrm{fami-}$ lies (Table 1 and Table 2). As for the number of individuals counted, it should be noted that it amounts to 1255 of which $31.71 \%$ are trees of $d^{1.30} \geq 10 \mathrm{~cm}$. The regenerative cohort $2 \leq \mathrm{d}^{0.20}<10 \mathrm{~cm}$ makes up $1 / 3$ of the count. The mean number of individuals per species is $37.26 \pm 6.05$ for a range of 2 to 137 plants per species (Table 2 and Figure 4). With more than 100 plants, Pentaclethra eetveldeana and Petersianthus macrocarpus account for $28.35 \%$ of the population. These taxa are followed by Carapa procera and Pentaclethra macrophylla with a number of plants ranging from 60 to 100, i.e. 19.03\% of the total. Finally, with at least 20 plants, Syzygium brazzavillense, Synsepalum dulcificum, Maranthes glabra, Pycnanthus angolensis, Millettia laurentii, Bosqueiopsis gilletii, Millettia eetveldeana, Ongokea gore and Anisophyllea meniaudi form the third group, accounting for $43.17 \%$ of the population. The least represented group of species, less than 20 plants, covers $9.45 \%$ of the inventory and consists of Xylopia acutiflora, Dialium pachyphyllum, Allablanckia floribunda, Tetraberlinia sp., Symphonia globulifera, Pterocarpus soyauxii, Albizia ferruginea, Celtis mildbraedii, Anonidium mannii and Paramacrolobium coeruleum.

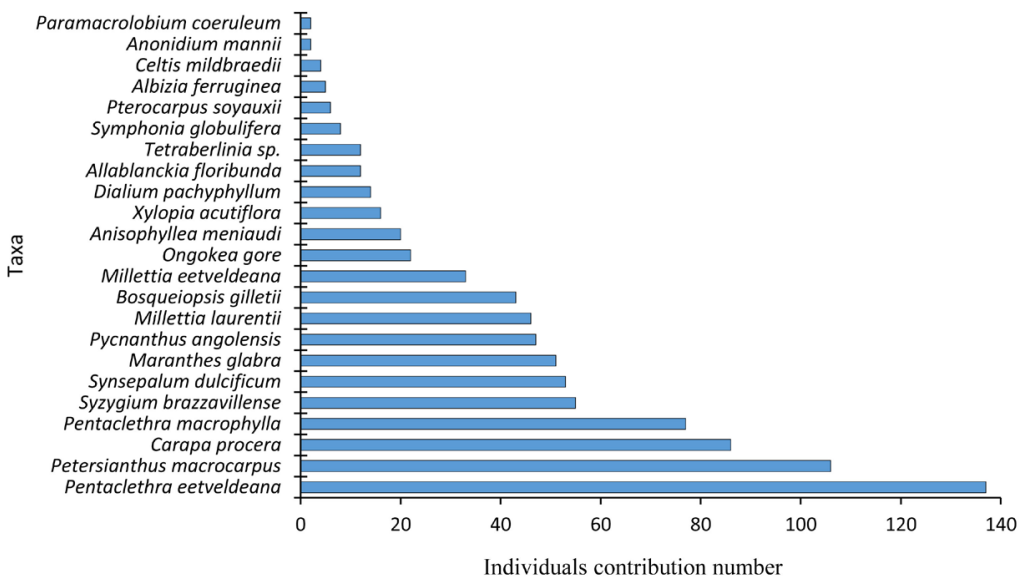

Figure 4. Number of individuals in the regenerative cohort by species. 
Table 1. Structural parameters of taxa involved in the regenerative study.

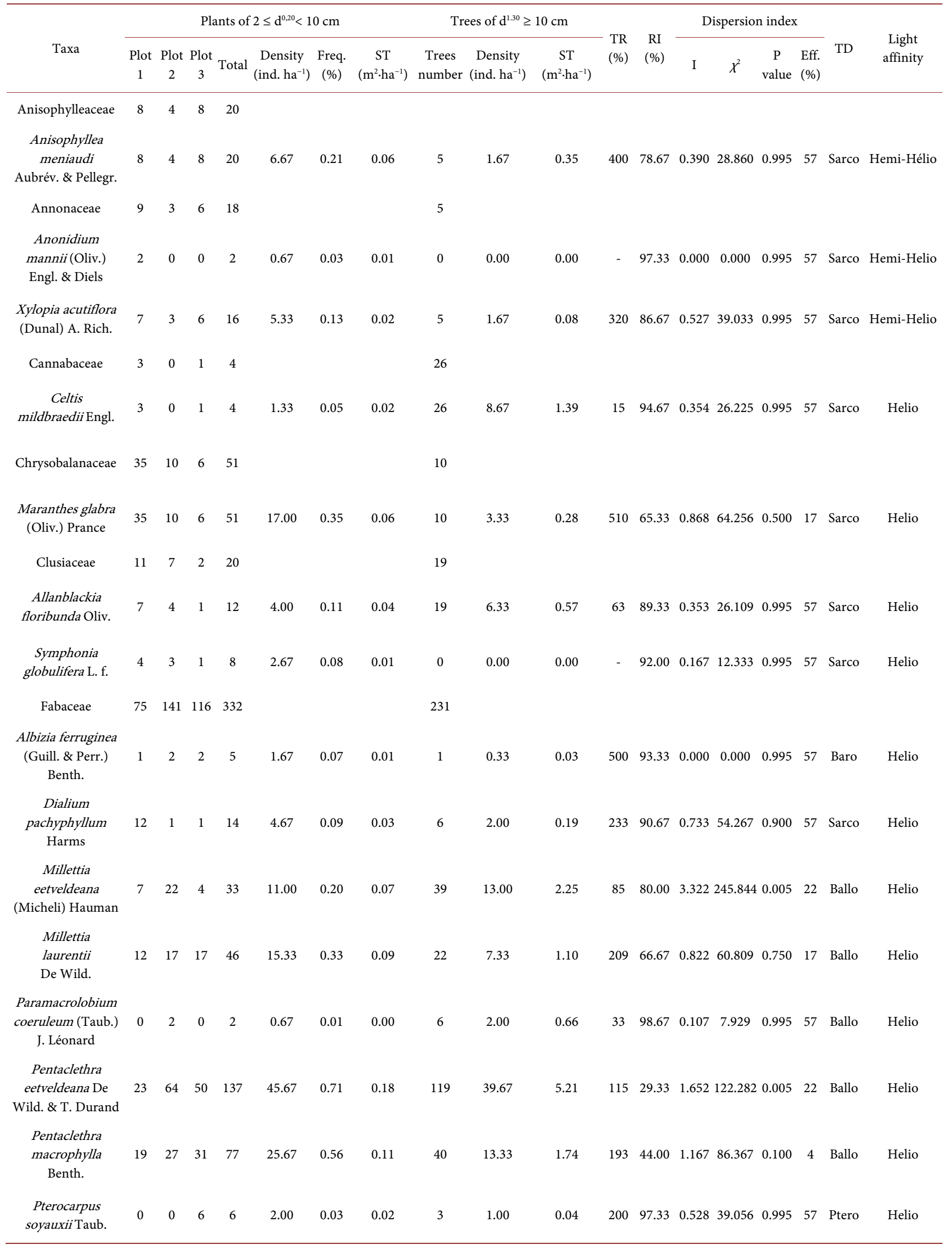




\section{Continued}

\begin{tabular}{|c|c|c|c|c|c|c|c|c|c|c|c|c|c|c|c|c|c|c|}
\hline Tetraberlinia $s p$ & 1 & 6 & 5 & 12 & 4.00 & 0.09 & 0.05 & 0 & 0.00 & 0.00 & - & 90.67 & 0.452 & 33.476 & 0.995 & 57 & Ballo & Helio \\
\hline Lecythidaceae & 41 & 44 & 21 & 106 & & & & 34 & & & & & & & & & & \\
\hline $\begin{array}{c}\text { Petersianthus } \\
\text { macrocarpus } \\
\text { (P. Beauv.) Liben }\end{array}$ & 41 & 44 & 21 & 106 & 35.33 & 0.59 & 0.23 & 34 & 11.33 & 1.49 & 312 & 41.33 & 1.469 & 108.720 & 0.005 & 22 & Ptero & Helio \\
\hline Meliaceae & 33 & 45 & 8 & 86 & & & & 15 & & & & & & & & & & \\
\hline $\begin{array}{c}\text { Carapa } \\
\text { procera DC. }\end{array}$ & 33 & 45 & 8 & 86 & 28.67 & 0.56 & 0.12 & 15 & 5.00 & 0.30 & 573 & 44.00 & 1.454 & 107.568 & 0.005 & 22 & Sarco & Helio \\
\hline Moraceae & 16 & 14 & 13 & 43 & & & & 27 & & & & & & & & & & \\
\hline Bosqueiopsis & & & & & & & & & & & & & & & & & & \\
\hline $\begin{array}{l}\text { gilletii De Wild. } \\
\text { \& T. Durand }\end{array}$ & 16 & 14 & 13 & 43 & 14.33 & 0.39 & 0.08 & 27 & 9.00 & 0.72 & 159 & 61.33 & 0.466 & 34.501 & 0.995 & 57 & Sarco & Helio \\
\hline Myristicaceae & 20 & 19 & 8 & 47 & & & & 12 & & & & & & & & & & \\
\hline $\begin{array}{c}\text { Pycnanthus } \\
\text { angolensis } \\
\text { (Welw.) Warb. }\end{array}$ & 20 & 19 & 8 & 47 & 15.67 & 0.37 & 0.09 & 12 & 4.00 & 0.95 & 392 & 62.67 & 0.999 & 73.957 & 0.250 & 17 & Sarco & Helio \\
\hline Myrtaceae & 12 & 17 & 26 & 55 & & & & 5 & & & & & & & & & & \\
\hline $\begin{array}{c}\text { Syzygium } \\
\text { brazzavillense } \\
\text { Aubrév. \& Pellegr. }\end{array}$ & 12 & 17 & 26 & 55 & 18.33 & 0.39 & 0.07 & 5 & 1.67 & 0.37 & 1100 & 61.33 & 0.967 & 71.533 & 0.250 & 17 & Sarco & Helio \\
\hline Olacaceae & 12 & 5 & 5 & 22 & & & & 1 & & & & & & & & & & \\
\hline $\begin{array}{l}\text { Ongokea gore } \\
\text { (Hua) Pierre }\end{array}$ & 12 & 5 & 5 & 22 & 7.33 & 0.21 & 0.05 & 1 & 0.33 & 0.02 & 2200 & 78.67 & 0.343 & 25.361 & 0.995 & 57 & Sarco & Helio \\
\hline Sapotaceae & 20 & 14 & 19 & 53 & & & & 3 & & & & & & & & & & \\
\hline $\begin{array}{c}\text { Synsepalum } \\
\text { dulcificum } \\
\text { (Schumach. \& } \\
\text { Thonn.) Daniell }\end{array}$ & 20 & 14 & 19 & 53 & 17.67 & 0.35 & 0.08 & 3 & 1.00 & 0.12 & 1767 & 65.33 & 1.497 & 110.804 & 0.005 & 22 & Sarco & Hemi-Scia \\
\hline Total & 295 & 323 & 239 & 857 & 285.67 & - & 1.48 & 398 & 132.67 & 17.89 & - & - & - & - & - & - & - & - \\
\hline Moyenne \pm ES & - & - & - & 285.67 & \pm 24.69 & - & $0.49 \pm 0.06$ & 132.6 & \pm 8.97 & $5.96 \pm 0.67$ & - & - & - & - & - & - & - & - \\
\hline
\end{tabular}

Table 2. Summary of taxonomic and floristic data.

\begin{tabular}{cccccc}
\hline \multirow{2}{*}{ Survey } & \multicolumn{3}{c}{ Taxa } & \multicolumn{2}{c}{ Individuals number } \\
\cline { 2 - 6 } & Families & Genera & Species & $2 \leq \mathrm{d}^{0.20}<10 \mathrm{~cm}$ & $\mathrm{~d}^{1.30} \geq 10 \mathrm{~cm}$ \\
\hline Plot $_{1}$ & 13 & 19 & 21 & 295 & 120 \\
Plot $_{2}$ & 12 & 18 & 20 & 323 & 150 \\
Plot & 13 & 19 & 21 & 239 & 128 \\
Total & 13 & 21 & 23 & 857 & 398 \\
Average \pm ES & $12.67 \pm 0.33$ & $18.67 \pm 0.33$ & $20.67 \pm 0.33$ & $285.67 \pm 24.69$ & $132.67 \pm 8.97$ \\
\hline
\end{tabular}

\subsection{Structure Parameters}

\subsubsection{Floral Density}

Floral density Trees of $\mathrm{d}^{1.30} \geq 10 \mathrm{~cm}$ have an average density of $132.67 \pm 8.97 \mathrm{in}$ dividuals $\mathrm{ha}^{-1}$. This density is supported by 4 taxa (Pentaclethra eetveldeaena, Pentaclethra macrophylla, Petersianthus macrocarpus, Millettia eetveldeana) whose number of trees per unit area is in the range 11 - 39. As for the regenera- 
tive cohort $\left(2 \leq \mathrm{d}^{0.20}<10 \mathrm{~cm}\right)$ the mean density is $285.67 \pm 24.69$ individuals $\mathrm{ha}^{-1}$. Notwithstanding the variations observed in the surveys, the dominant taxa in this category are Pentaclethra eetveldeaena, Petersianthus macrocarpus, Carapa procera, Pentaclethra macrophylla. Maranthes glabra, Millettia eetveldeana, Millettia laurentii, Bosqueiopsis gilletii, Pycnanthus angolensis, Syzygium brazzavillensis, Synsepalum dulcificum. These species have an average of 11 to 45 individuals ha ${ }^{-1}$ (Table 1). The mean number of individuals does not vary significantly ( $\mathrm{p}$-value $=0.1818$ for the ANOVA test) between surveys. The mean absolute densities of the surveys, for all diameter classes (regenerative cohort and large-diameter trees combined), do not vary significantly ( $\mathrm{p}$-value $=0.1706$ for the ANOVA test). This observation is synonymous with a random distribution of individuals within the woody formation.

\subsubsection{Frequency of Taxa}

Considering the sampling units, the frequency of the regenerative cohort $(2 \leq$ $\mathrm{d}^{0.20}<10 \mathrm{~cm}$ ) varies from 0.01 to $0.71 \%$, or an average of $0.26 \pm 0.04$ (Table 1). $82.61 \%$ of the species are present in all 3 surveys; $13.04 \%$ restricted to $1 / 3$ of the surveys; and finally $4.35 \%$ restricted to $2 / 3$ of the surveys. The distribution of taxa shows floristic heterogeneity.

\subsubsection{Basal Surface Area of Taxa}

The average basal area of the trees of $\mathrm{d}^{1.30} \geq 10 \mathrm{~cm}$ is $5.96 \pm 0.67 \mathrm{~m}^{2} \cdot \mathrm{ha}^{-1}$, for a range between 4.63 and $6.79 \mathrm{~m}^{2} \cdot \mathrm{ha}^{-1}$. The regenerative cohort $\left(2 \leq \mathrm{d}^{0.20}<10 \mathrm{~cm}\right)$ has a mean basal area of $0.49 \pm 0.06 \mathrm{~m}^{2} \cdot \mathrm{ha}^{-1}$, for a range of values from 0.39 to $0.61 \mathrm{~m}^{2} \cdot \mathrm{ha}^{-1}$ (Table 1). Mean basal area values showed a significant difference for regeneration individuals ( $\mathrm{p}$-value $=0.04299$ for the ANOVA test) between surveys 2 and 3 for which the Student test gave a p-value $=0.044$. However, the differences are not significant between the mean basal area values for large diameter individuals ( $\mathrm{p}$-value $=0.4835$ for the ANOVA test) within the surveys. The mean basal area values do not differ significantly ( $\mathrm{p}$-value $=0.2357$ for the ANOVA test) within the surveys for all diameter classes.

\subsubsection{Vertical Stratification of the Regenerative Cohort}

Most of the individuals surveyed belong to stratum II, regardless of the survey (Figure 5). This observation is also valid for the ecosystem as a whole, with $59.76 \%$ of the individuals surveyed. The Kruskal-Wallis test does not reveal any significant differences between the median height values of the three surveys (p-value $=0.9853)$. However, highly significant differences were observed between the height values in the different strata ( $\mathrm{p}$-value $<2.2 \times 10^{-16}$ ). This observation is supported by the Wilcoxon and Mann-Whitney test with $\mathrm{p}$-value $<0.05$ (Megaphanerophytes - Mesophanerophytes $=3.1 \times 10^{-13}$; Megaphanerophytes Microphanerophytes $=2.7 \times 10^{-13}$; Megaphanerophytes - Nanophanerophytes = $2.3 \times 10^{-10}$; Mesophanerophytes - Microphanerophytes $<2 \times 10^{-16}$; Mesophanerophytes - Nanophanerophytes $<2 \times 10^{-16}$; Microphanerophytes - Nanophanerophytes $<2 \times 10^{-16}$ ). 


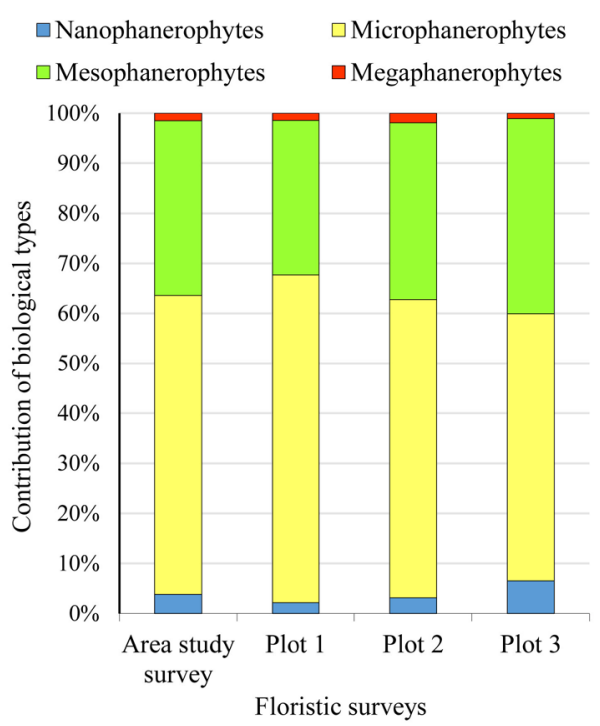

Figure 5. Vertical stratification of taxa in the Loukaya peri-urban Forest.

\subsubsection{Diameter Structure of Taxa}

Dendrometric data from trees of $\mathrm{d}^{1.30} \geq 10 \mathrm{~cm}$ show an inverted "L" or "J" shaped curve, indicating consistent recruitment between diameter classes (Figure 6(a) and Figure 6(b)). Notwithstanding this overall effect, specific monitoring of the taxa in the study revealed erratic curves (Figure 6). This observation is evidence of their poor natural regeneration. The mean values of the diameters of regeneration individuals within the surveys do not show significant differences ( $p$-value $=0.09187$ for the ANOVA test). The median values of the diameters of the individuals within the surveys do not show significant differences from one survey to another ( $\mathrm{p}$-value $=0.4545$ for the Kruskal-Wallis test). This data would reflect a similar evolution of the flower-bulb considered within the three surveys constituting the study area.

\subsection{Regenerative Cohort Height-Diameter Relationship}

A positive correlation was noted between the height and diameter of individuals monitored in the Loukaya peri-urban forest, regardless of the inventory level (Figure 7). The Spearman's coefficient ("rho") being, in all cases, higher than the Pearson's coefficient (" $r$ "), reflects a monotonous and non-linear relationship. This observation reveals that the diameter of individuals increases concomitantly with height, but not proportionally. This phenomenon could be a consequence of accidents occurring during their growth stages. These include 1) anthropogenic actions and natural accidents such as windfalls; 2) the diversity of growth rates of the species considered, as well as their distribution pattern within the study area.

\subsection{Phytodiversity Index}

\subsubsection{Species Depletion Index}

Of the 23 species monitored for regeneration $\left(2 \leq \mathrm{d}^{0.20}<10 \mathrm{~cm}\right), 52.17 \%$ have a 


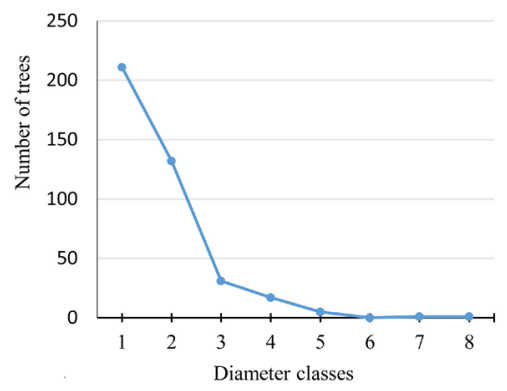

(a)

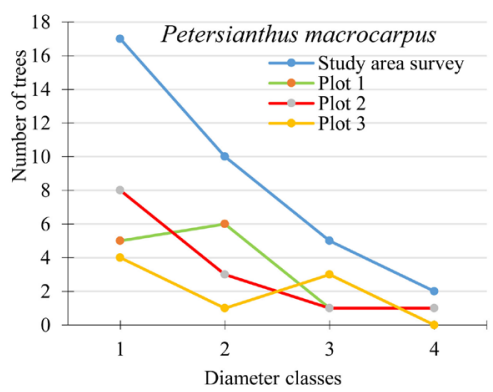

(c)

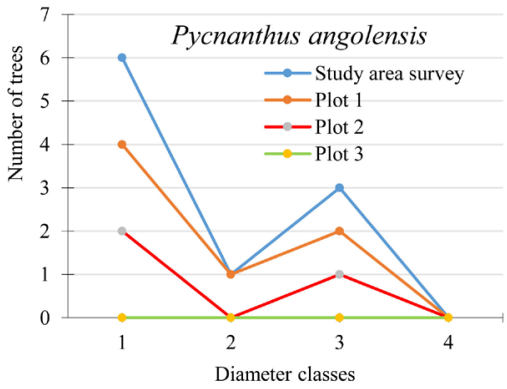

(e)

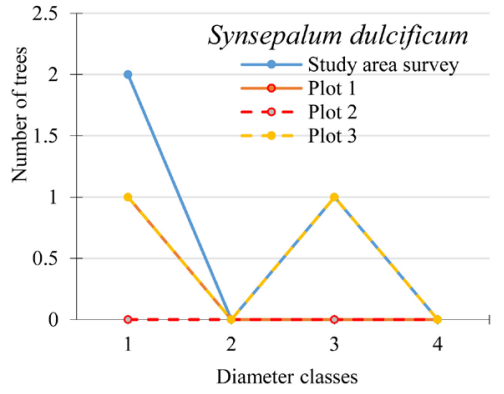

(g)

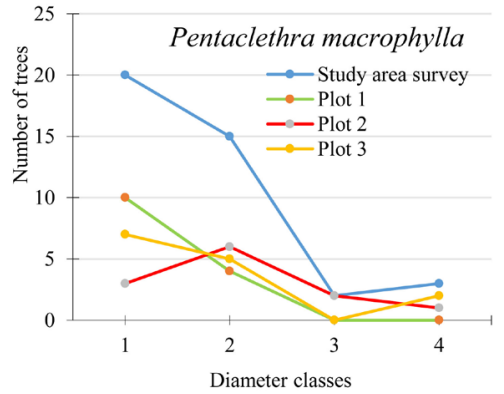

(i)

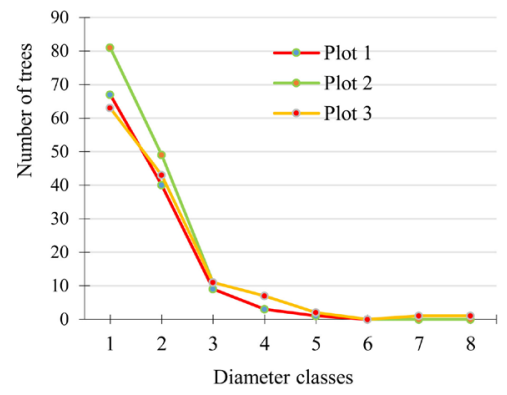

(b)

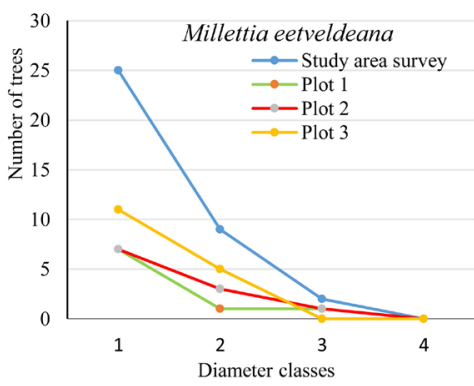

(d)

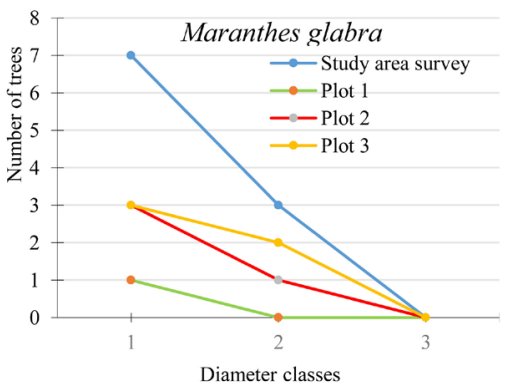

(f)

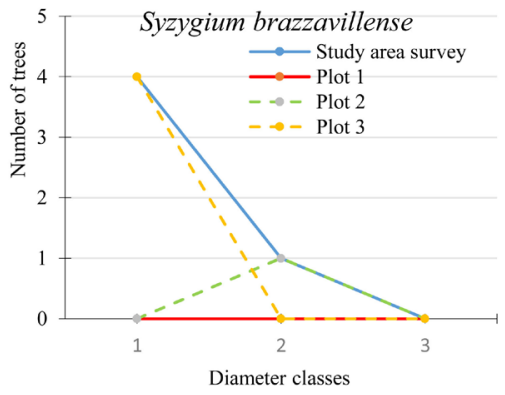

(h)

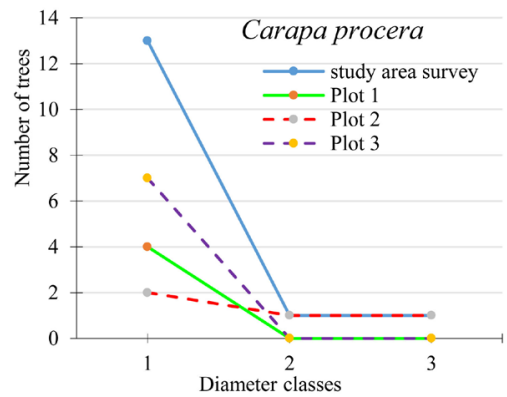

(j) 


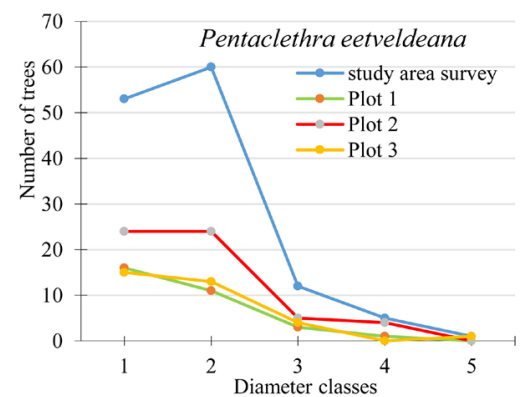

(k)

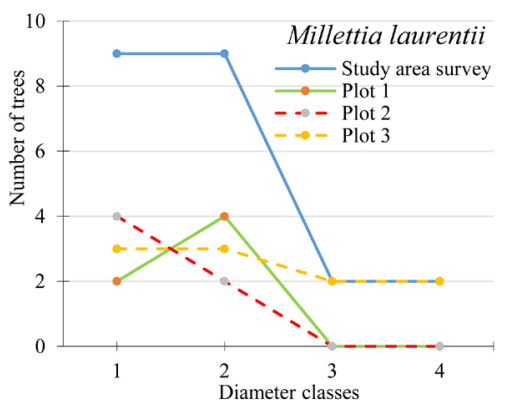

(m)

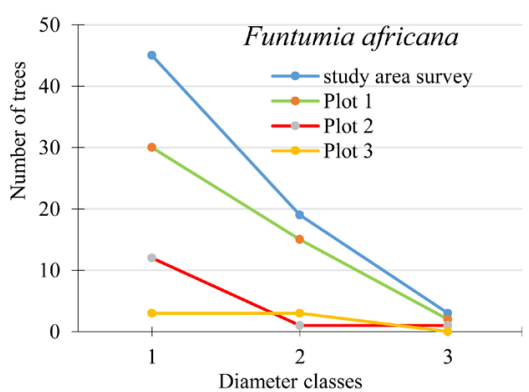

(1)

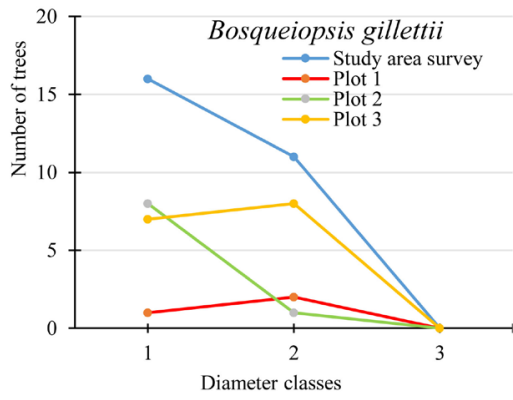

(n)

Figure 6. Diameter structure of the predominant species of the regenerative cohort. Legend: entire study area survey (a); per survey (b); species per plot and study area survey $((\mathrm{c})-(\mathrm{n}))$.

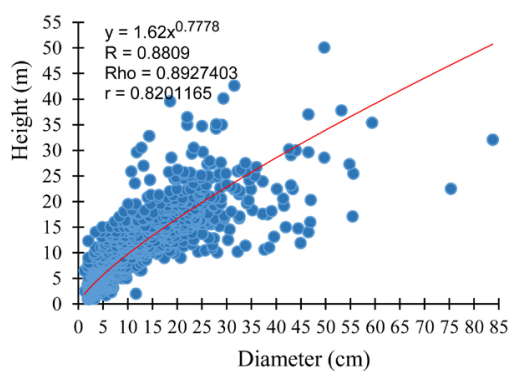

(a)

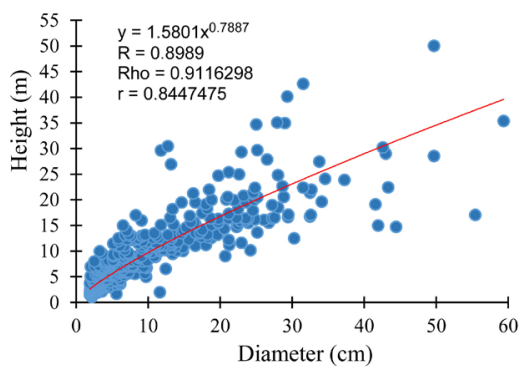

(c)

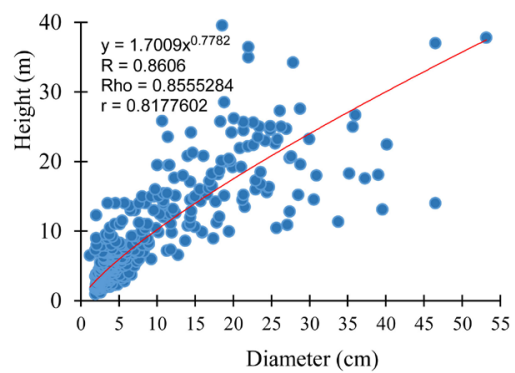

(b)

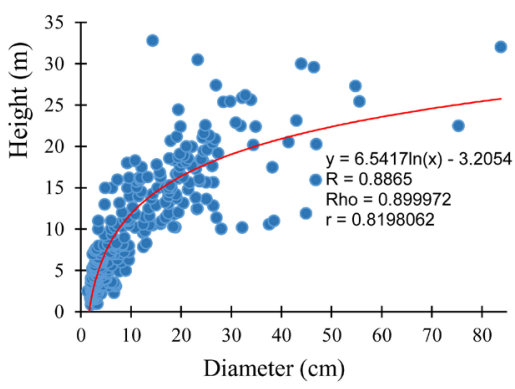

(d)

Figure 7. Height-diameter relationship of monitored regenerative taxa. (a): Study area; (b): Survey 1; (c): Survey 2; (d): Survey 3.

species rarity index (RI) of less than $80 \%$. These taxa with RI values ranging from $29.33 \%$ to $78.67 \%$ are abundant and include Maranthes glabra, Millettia laurentii, Pentaclethra eetveldeana, Pentaclethra macrophylla, Pycnanthus an- 
golensis, Petersianthus macrocarpum, Carapa procera. However, the remaining $47.83 \%$ have an IR between $80 \%$ and $98.67 \%$ (Table 1). Rare taxa in this category include Paramacrolobium coeruleum, Anonidium mannii, Pterocarpus soyauxii, Tetraberlinia sp., Allablanckia floribunda, Celtis mildbraedii, Dialium pachyphyllum, Symphonia globulifera.

\subsubsection{Coefficients of Floristic Similarity}

Regardless of the similarity coefficient (Jaccard or Sørensen), the floristic composition is very homogeneous between the surveys. Jaccard's similarity coefficient is on average $87.67 \pm 1.67$, compared to $93.67 \pm 0.67$ for Sørensen. The differences are not significant between surveys ( $\mathrm{p}$-value $=0.6853$ for the ANOVA test).

\subsubsection{Natural Regeneration Rate}

At the scale of the study, the natural regeneration rate is $215.33 \%$. In contrast, in surveys 1, 2 and 3, the respective rates are $245.83 \% ; 215.33 \%$ and $178.36 \%$, from the specific level (Table 1). The observation of the rate of natural regeneration declines for 3 taxa groups. The first group, with TR $>1000 \%$, consists of $13.04 \%$ of species with very good natural regeneration (Ongokea gore, Synsepalum dulcificum and Syzygium brazzavillense); the second, with $56.52 \%$ of the inventory and a rate of $100 \leq \mathrm{TR}<1000 \%$, consists of species with good natural regeneration (Carapa procera, Maranthes glabra, Albizia ferruginea, Anisophyllea meniaudi, Pycnanthus angolensis, Xylopia acutiflora, Petersianthus macrocarpus, Dialium pachyphyllum, Millettia laurentii, Pterocarpus soyauxii, Pentaclethra macrophylla, Bosqueiopsis gilletii and Pentaclethra eetveldeana); and finally, the last group, with $30.44 \%$ of taxa and a TR rate $<100 \%$, includes all species with poor natural regeneration (Millettia eetveldeana, Allablanckia floribunda, Paramacrolobium coeruleum, Celtis mildbraedii, Tetraberlinia sp., Symphonia globulifera and Anonidium mannii).

\subsubsection{Taxa Dispersion Index}

The dispersion index (I) applied to the 23 species (i.e. 1255 individuals) in the study area reveals that $22 \%$ of species corresponding to 625 trees show significant gregarious dispersion $\left(\chi^{2} ; \mathrm{p}\right.$ value $\left.<0.05\right)$ (Table 1). Pentaclethra macrophylla alone gathering 117 individuals, or $4 \%$ of the floristic richness of the phytocenosis, presents a non-significant gregarious dispersion $\left(\chi^{2} ; p\right.$-value $\left.>0.05\right)$. Uniform dispersal is found in $57 \%$ of species (265 individuals) of the phytocenosis. However, this hyperdispersion remains non-significant in view of the results of the Chi-square test $\left(\chi^{2} ; \mathrm{p}\right.$ value $\left.>0.05\right)$. This study area covers $17 \%$ of species with a non-significant random dispersion $\left(\chi^{2} ; \mathrm{p}\right.$ value $\left.>0.05\right)$ whose density is evaluated at 248 (Table 1).

\subsection{Diaspora Types and Affinity in the Light of Taxa}

Sarcochores are preponderant with $60.87 \%$ of the species, corresponding to a proportion of $50.53 \%$ of individuals (Figure 8(a) and Figure 8(b)). Ballochores 


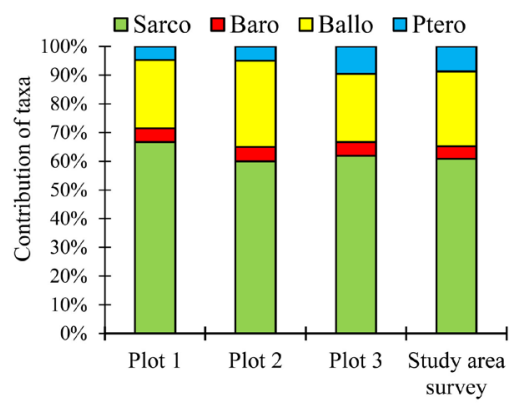

(a)

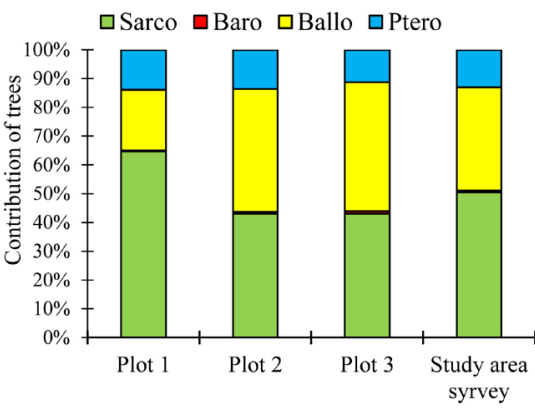

(b)

Figure 8. Spectrum of diaspora types. Legend: Raw spectrum (a); Weighted spectrum (b), Sarcochores (Sarco), Barochores (Baro), Ballochores (Ball), Pterochores (Ptero).

come in the second position with $26.09 \%$ of the species and $35.82 \%$ of the individuals. This observation made at the scale of the study is also valid when considering the surveys, where sarcochores remain dominant ahead of horehounds.

In relation to light affinity, $82.61 \%$ of the species surveyed are heliophilic, i.e. 89.39\% of individuals (Figure 9(a)). The hemi-heliophilic plants have a specific proportion of $13.04 \%$, while hemi-sciaphiles are ahead of them in terms of individuals with $6.18 \%$ of the individuals recorded (Figure $9(\mathrm{~b})$ ).

\section{Discussion}

\subsection{Analysis of Phytodiversity}

Like all the intra-urban and peri-urban forests in Brazzaville (Patte d'Oie and Djoumouna Forests) whose phytodiversity data are almost under control, the Loukaya woodland formation is no exception. Mesophilic and tropophilic in type, the Loukaya forest is a very diverse and concomitantly tree-poor formation [10] [16] [51] [52] [53] [54] [55]. This state is the tangible result of anthropogenic effects that severely impact all levels of biodiversity $(\alpha, \beta, \gamma)$. These woody formations, although they are part of the dense tropical rainforests, without being compared to the neotropical and palaeotropical forest ecosystems of South-East Asia, are very atypical in terms of specific and floristic richness [52]. These structural parameters would be dependent on pedoclimatic determinism, in general. These indices establish the link of their belonging to the physiographic area of the Cataractes district [10] [16] [51] [52] [53] [54] [56].

The passage from one diameter class to another induces a decrease in density following the conquest of space, which is not extensible [20] [57] [58]. Thus, high mortality of juvenile individuals $\left(2 \leq \mathrm{d}^{0.20}<10 \mathrm{~cm}\right)$ is observed under the influence of intrinsic and extrinsic factors (descent of peaks, trampling, irregularity of rainfall, grazing) as mentioned in several works [10] [13] [17] [59] [60] [61]. As a result of the high mortality rate among the regenerative cohort, Baraloto [57] points out that barely $1 \%$ of seedlings (germinated seeds) reach adulthood in tropical forests. Notwithstanding the natural events that affect natural regeneration in the forest, the share associated with humans would be preponderant in this ecosystem. The disturbance in the recruitment of taxa within 


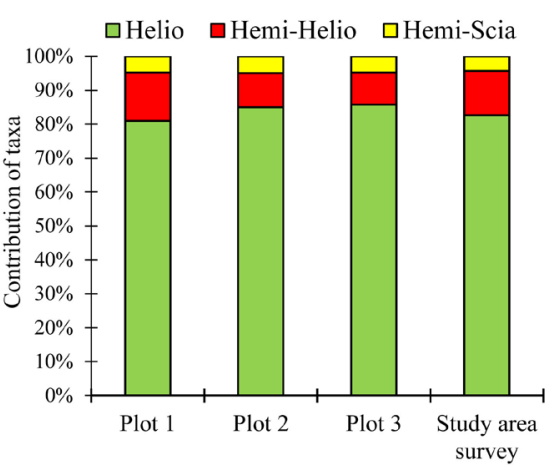

(a)

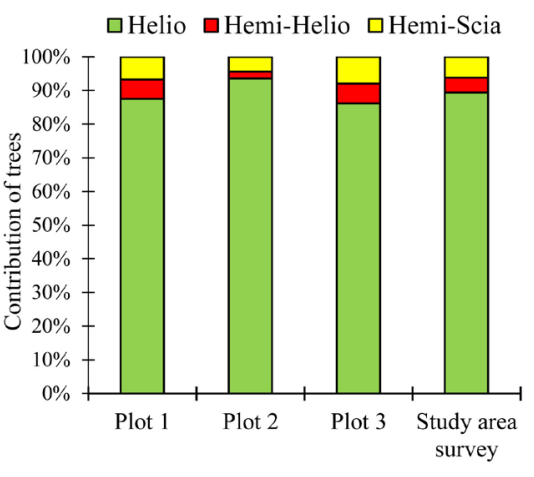

(b)

Figure 9. Spectrum of light affinity types. Legend: Raw Spectrum (a), Weighted Spectrum (b), Heliophile (Heli), Hemi-heliophile (Hemi-Helio), Hemi-Sciaphile (Hemi-Scia).

diameter classes $\left(\mathrm{d}^{1.30} \geq 10 \mathrm{~cm}\right)$, which is at the origin of the erratic curves for each of the species monitored, is irrefutable proof of recurrent anthropogenic interventions [10] [16] [20] [51] [52] [53] [54] [55] [62]. The corollaries of this ever-increasing and continuous anthropogenic pressure have a lasting impact on the natural regeneration of these taxa and concomitantly that of the entire ecosystem.

\subsection{Status of Natural Regeneration}

The natural regeneration of a forest is supported by the ratio of seedlings to large trees in the stand [63] [64] [65]. As such, natural regeneration is the basis for understanding the dynamics of woody vegetation, integrating the process of diametric recruitment, juvenile mortality, developmental stages and ecosystem survival [62] [66]. Under the dependence of several factors (light intensity, humidity, nature of the substrate, biological characteristics), natural regeneration would be a phenomenon sensitive to the variation of environmental parameters [67]. Correlatively, the modification of the parameters of the Loukaya ecosystem, following the various anthropic actions of the local residents, would explain some of the results of this study, particularly the mortality of young plants [1].

The Loukaya forest, which is much secondarised, looks like an ecosystem in full recovery, taking into account the high rate of young plants of heliophilic species (Ongokea gore and Syzygium brazzavillense). These stages of forest recovery are generally marked by a massive presence of pioneer heliophilic species [68]. A high level of anthropisation affects the physiognomy of the forest facies through the opening of the gaps. The corollaries are a variation in the flow of light reaching the ground, directly or through the heat, it brings generally considered as a determining factor in the renewal of forest stands [69] [70] [71]. This parameter would explain the high rate of seedlings in the study area; confirmed by a regeneration index greater than $100 \%$; synonymous with good regeneration on the Rothe scale [48].

Also, it should be noted that the type of diaspora and the mode of dissemination effectively intervene in the process of densification of regenerants. The do- 
minance of sarcochores in the Lukaya forest induces high densities of regenerants subject to predation and high mortality due to intraspecific competition at the base of the productive trees [57] [59] [72] who reports that in tropical forests confirms this hypothesis, only $1 \%$ of the individuals at the base of the productive trees reach maturity.

Although the natural regeneration index is satisfactory, the absence of individuals in certain diameter classes indicates that the process is subject to disturbances whose primary origin is human activity. Peri-urban forests are excellent places for supplying the surrounding populations with daily basic needs [73] [74] [75].

\subsection{Spatial Structure and Dispersion of Diasporas}

The spatial distribution of a species results from the interaction of biotic and abiotic factors, and as long as resources are not too limiting [76] [77]. Under these conditions, dissemination becomes the main spatial limitation and therefore determines the probability of recruitment [78] [79] [80]. As the Loukaya peri-urban forest is dominated by sarcochorous species, endozoochory is the main mode of spread. Human practices in peri-urban ecosystems, including hunting, are factors limiting spread, due to pressure on wildlife. Thus, the observed aggregate distribution of individuals of $2 \leq \mathrm{d}^{0.20}<10 \mathrm{~cm}$ would be the result of the limitation of dispersal [76] [80] [81] [82].

Anthropogenic activities in this ecosystem (hunting and cutting of trees and small woods) have a direct impact on biodiversity in general and indirectly on the dispersion of diasporas, especially sarcochores. These diasporas, which cannot ensure long-distance dispersal without animal involvement, give an aggregated spatial structure to the taxa of the regenerative cohort. Gaps or even windfalls are appropriate environments for the development of this phenomenon, as they provide optimal conditions for germination and growth of individuals [20] [83] [84]. Windfalls and open gaps resulting from natural and/or artificial events are important niches for regeneration [85].

Finally, it should be noted that the aggregate structure of the regenerative cohort evolves towards a random structure over time. Since the vital area is not extensible, recruitment within diameter classes affects densities, in the sense of regression. Indeed, the larger the trees, the lower their density [20] [62]. This evolution of structure would be the result of the mortality dependence mechanism of the individuals, which often corresponds to the transition from the young to the adult stage following intraspecific competition and that of water and mineral resources [86].

\section{Conclusion}

The peri-urban forest of Loukaya is subject to an exceptional level of anthropic pressure, which negatively affects biodiversity in all three dimensions. In this tropophilic and mesophilic ecosystem, anthropic activities would be the cause of 
the poor generation of the woody population, especially sarcochorous taxa. The flora-fauna association in tropical forests is fundamental to their dynamics. In the peri-urban forest of Loukaya, as everywhere else, natural regeneration is strongly influenced by several parameters, notably the mode of dispersal and the various biotic and abiotic factors. The distribution of the regenerative cohort is dependent on the dispersal power of the taxa. These dispersal mechanisms determine the structure and fate of the stands. The absence of the agents of dissemination is at the origin of the aggregative structure of the regenerants, the corollaries of which are a high level of inter- and intra-species competition for available soil resources. The high frequency of regenerants coupled with their exceptionally high rate in windfalls and gaps are clear indications of the intensity and quantity of light reaching the undergrowth. Thus, light remains one of the essential elements in the development of the regenerating cohort.

\section{Acknowledgements}

We are grateful to the people of the BISINDZA village for their unfailing availability and enthusiasm for environmental issues, particularly the sustainable management of forest ecosystems.

\section{Conflicts of Interest}

The authors declare no conflicts of interest regarding the publication of this paper.

\section{References}

[1] Koubouana, F., Ifo, S.A., Mayitoukou, L. and Ndinga, E. (2016) Diversité floristique et dynamique de reconstitution de la forêt du parc zoologique sous plantation à Eucalyptus à Brazzaville; Congo. International Journal of Biological and Chemical Sciences, 10, 609-619. https://doi.org/10.4314/ijbcs.v10i2.13

[2] Daily, G.C., Alexander, S., Ehrlich, P.R., Goulder, L., Lubchenco, J., Matson, P.A., Mooney, H.A., Postel, S., Schneider, S.H., Tilman, D. and Woodwell, G.M. (1997) Ecosystem Services: Benefits Supplied to Human Societies by Natural Ecosystems. Issues in Ecology (Ecological Society of America), 2, 1-16.

[3] Barnaud, C., Corbera, E., Muradian, R., Salliou, N., Sirami, C., Vialatte, A., Choisis, J.-P., Dendoncker, N., Mathevet, R., Moreau, C., Reyes-García, V., Boada, M., Deconchat, M., Cibien, C., Garnier, S., Maneja, R. and Antona, M. (2018) Ecosystem Services, Social Interdependencies, and Collective Action: A Conceptual Framework. Ecology and Society, 23, 15. https://doi.org/10.5751/ES-09848-230115

[4] Serpantié, G., Méral, P. and Bidaud, C. (2012) Des bienfaits de la nature aux services écosystémiques. http://vertigo.revues.org/12924

[5] Raquez, P. and Dendoncker, N. (2013) Dossier scientifique sur les services rendus par les écosystèmes en Wallonie, en vue de la préparation du rapport analytique 2012-2013 sur l'état de l'environnement wallon. Université de Namur-Département de Géographie.

[6] Coutts, C. and Hahn, M. (2015) Green Infrastructure, Ecosystem Services, and Human Health. International Journal of Environmental Research and Public Health, 12, 9768-9798. https://doi.org/10.3390/ijerph120809768 
[7] MEA (2005) Ecosystems and Human Well-Being: Synthesis. Island Press, Washington DC.

[8] Kassi N’Dja, J. and Decocq, G. (2007) Régénération de la forêt dense semi-décidue dans les stades post-culturaux en forêt classée de Sanaimbo (Côte-d'Ivoire). Acta Botanica Gallica, 154, 395-405. https://doi.org/10.1080/12538078.2007.10516072

[9] Kassi N’Dja, J., Ake-Assi, E. and Tiebre, M.S. (2010) Biodiversité végétale et vitesse de la régénération de la forêt classée de Sanaimbo (Côte d'Ivoire). Sciences \& Nature, 7, 195-206. https://doi.org/10.4314/scinat.v7i2.59963

[10] Kimpouni, V., Mbou, P., Gakosso, G. and Motom, M. (2013) Biodiversité floristique du sous-bois et régénération naturelle de la forêt de la Patte d'Oie de Brazzaville, Congo. International Journal of Biological and Chemical Sciences, 7, 1255-1270. https://doi.org/10.4314/ijbcs.v7i3.31

[11] Adingra, O.M.M.A., Kassi N’Dja, J. and Yongo, O.D. (2014) Analyse systématique et phytogéographique de la forêt classée de la Bamo (Côte d'Ivoire). Journal of Animal \& Plant Sciences, 23, 3626-3636. http://www.m.elewa.org/JAPS

[12] Madzella-Mbiemo, I.M. (2018) Biens et services écosystémiques associés à la forêt péri-urbaine de la Djoumouna. Mémoire de master, ENS, UMNG.

[13] Agbangla, M.M., Aoudji, A.K.N., Akouehou, G.S., Gbetoho, J.A., Sanon, K., Ayina, O., de Chanière, C. and Ganglo, J.C. (2015) Caractéristiques structurales et écologiques des populations d'espèces commerciales: une base pour la sylviculture dans les peuplements forestiers de Niaouli (Sud-Benin). Tropicultura, 33, 238-252.

[14] PEEDU (2016) Schéma Directeur d'Urbanisme de la ville de Brazzaville. KEIOS Development Consulting, Brazzaville.

[15] FAO (2001) Urban and Peri-Urban Forestry: Case Studies on Developing Countries. FAO, Rome.

[16] Kimpouni, V., Mbou, P., Apani, E. and Motom, M. (2014) Étude floristique des îlots forestiers naturels de la Patte d'Oie de Brazzaville, Congo. Acta Botanica Gallica, 155, 323-334. https://doi.org/10.1080/12538078.2013.870048

[17] Gakosso, G. (2009) Diversité floristique et potentialité régénérative des îlots forestiers naturels de la Patte d'Oie. Mémoire de CAPES, ENS, UMNG.

[18] Massamba-Makanda, C.-M. (2017) Phytodiversité et paramètres structuraux de la forêt péri-urbaine de la Djoumouna, Brazzaville (Congo). Mémoire de Master, Université Marien Ngouabi.

[19] Kiongo-Mbingou, F.A. (2018) Influence de la couverture pédologique sur la composition floristique de la forêt périurbaine de la Djoumouna, Brazzaville (Congo). Mémoire de Master d'Aptitude au Professorat de l'Enseignement Secondaire (MAPES) Sc. Nat., U.M.NG.

[20] Puig, H. (2001) La forêt tropicale humide. Belin, Paris.

[21] Poinsier, J.-L. (1947) Le parasolier: Essence de reboisement pour la forêt secondaire. Bois et Forêts des Tropiques, 3, 31-34.

[22] Loumoua, R.F.C. (2014) Etude quantitative de la forêt à Pentaclethra eetveldeana De Wild \& Th. Durand de Mayitoukou (Sous-préfecture de Goma-Tsé-Tsé, Département du Pool). Mémoire d'Ingénieur de Développement Rural, UMNG.

[23] Miabangana, E.S. and Lubini Ayingweu, C. (2015) Analyse floristique et phytogéographique de la végétation de l'île Loufézou à Brazzaville (République du Congo). Revue Internationale de Géologie, de Géographie et d'Écologie Tropicales, 39, 55-66.

[24] Miabangana, E.S., Lubini Ayingweu, C. and Malaisse, F. (2016) Analyse floristique 
et phytogéographique de la forêt de la Djoumouna (République du Congo). Revue Internationale de Géologie, de Géographie et d'Écologie Tropicales, 40, 175-190.

[25] Denis, B. (1974) Carte pédologique Brazzaville-Kinkala. Notice explicative $n^{\circ} 52$. République du Congo à 1/200.000. Centre ORSTOM de Brazzaville, Paris.

[26] Vennetier, P. (1966) Géographie du Congo-Brazzaville. Centre d'enseignement supérieur de Brazzaville, Gauthier-Villars-Paris.

[27] Samba, G. (2020) Le climat du Congo Brazzaville. Collection études africaines, L'Harmattan, Paris.

[28] Samba-Kimbata, M.-J. (1978) Le climat Bas congolais. Thèse de doctorat, Université de Dijon, Dijon.

[29] Descoings, B. (1969) Esquisse phytogéographique du Congo. Bondy, ORSTOM, Paris.

[30] Descoings, B. (1975) Les grandes régions naturelles du Congo. Candollea, 30, 91-120.

[31] Ramananjatovo, R. (2013) Etude structurale et écologique de la régénération naturelle de la flore dans deux zones à différents degrés de perturbation dans la Réserve Spéciale de Bezà Mahafaly. Mémoire d’ingénieur, Ecole Supérieure des Sciences Agronomiques, Université d'Antananarivo.

[32] APG IV (2016) An Updated of the Angiosperm Phylogeny Group Classifications for Orders and Families of Flowering Plants: APG IV. Botanical Journal of the Linnean Society, 181, 1-20. https://doi.org/10.1111/boj.12385

[33] Lebrun, J.-P. and Stork, A.L. (1991-2015) Enumeration of Flowering Plants in Tropical Africa and Tropical African Flowering Plants: Ecology and Distribution. The Conservatory and Botanical Garden of the City of Geneva, Geneva, 1-10. http://www.villege.ch/musinfo/bd/cjb/africa/recherche.php?langue=en

[34] Dansereau, P. and Lems, K. (1957) The Grading Dispersal Types in Plant Communities and Their Ecological Significance. Contrib. Inst. Bot. Univ. Montréal, $n^{\circ} 71$, 1-52.

[35] Lebrun, J. (1960) Etudes sur la flore et la végétation des champs de lave au nord du lac Kivu (Congo Belge). Institut des parcs nationaux du Congo belge, Mission J. Lebrun (1937-1938), Fascicule 2. Bruxelles.

[36] Moutsamboté, J.-M. (2012) Etude écologique, phytogéographique et phytosociologique du centre et du nord Congo-Brazzaville (Plateaux, Cuvette, Likouala et Sangha). Thèse d'Etat, Université Marien Ngouabi, Brazzaville.

[37] Lebrun, J. (1947) La végétation de la plaine alluviale au sud du lac Edouard. Institut des parcs nationaux du Congo belge, Mission J. Lebrun (1937-1938), Fascicule 1, Bruxelles.

[38] Évrard, C. (1968) Recherches écologiques sur le peuplement forestier des sols hydromorphes de la cuvette congolaise. Publication de l'Institut national pour l'Étude agronomique du Congo belge, Bruxelles, Série Scientifique 110, Bruxelles.

[39] Kompanyi Amissi, M. (2013) Etude comparative de la Régénération de Gilbertiodendron dewevrei (De Wild.) J. Léonard dans la Forêt de l'Ituri et celle des Environs de Kisangani. Travail de fin d'Etudes de Licence, Faculté des Sciences, Université de Kisangani.

[40] Tiokeng, B., Mapongmetsem, P.-M., Nguetsop V.F. and Tacham, W.N. (2015) Biodiversité floristique et régénération naturelle sur les Hautes Terre de Lebialem (Ouest Cameroun). International Journal of Biological and Chemical Sciences, 9 , 56-68. https://doi.org/10.4314/ijbcs.v9i1.6 
[41] Dallmeier, F. (1992) Long-Term Monitoring of Biological Diversity in Tropical Forest Areas, Methods for Establishment and Inventory of Permanent Plots. MAB Digest 11, UNESCO, Paris.

[42] Raunkiaer, C. (1934) The Life Forms of Plants and Statistical Plant Geography. Clarendon Press, Oxford.

[43] Makany, L. (1976) Végétation des plateaux Téké (Congo). Collection Travaux Université de Brazzaville. Université de Brazzaville, Brazzaville.

[44] Senterre, B. (2005) Recherches méthodologiques pour la typologie de la végétation et la phytogéographie des forêts denses d'Afrique tropicale. Thèse de doctorat, Université Libre de Bruxelles, Bruxelles. https://doi.org/10.1080/12538078.2005.10515499

[45] Kouob Bégné, S. (2009) Les forêts matures de terre ferme du sud-est Cameroun. Thèse de doctorat, Université Libre de Bruxelles, Bruxelles. https://dipot.ulb.ac.be/dspace/bitstream/2013/210222/15/32796094-7b11-40ce-820a -d28c24522172.txt

[46] Géhu, J.M. and Géhu, J. (1980) Essai d'objectivation de l'évaluation biologique des milieux naturels. Exemples littoraux. In: Géhu, J.M., Ed., Séminaire de phytosociologie appliquée, Amicale francophone de phytosociologie, 75-94.

[47] Magurran, A.M. (2004) Measuring Biological Diversity. Blackwell Science Ltd., Oxford.

[48] Rothe, P.L. (1964) Régénération naturelle en forêt tropicale: Le Dipterocarpusdyeri (Dau) sur le versant cambodgien du golfe du Siam. Bois et Forêt des Tropiques, 8 , 386-397.

[49] Bariteau, M. (1992) Régénération naturelle de la forêt tropicale humide de Guyane: Étude de la répartition spatiale de Qualea rosea Aublet, Eperua falcata Aublet et Symphonia globulifera Linnaeus f. Annales des sciences forestières, 49, 359-382. https://doi.org/10.1051/forest:19920405

[50] Nanga Mebenga, R.L. (2009) Distribution spatiale des semis de Pericopsis elata (Harms) Van Meeuwen dans la concession forestière de Green Valley inc. à Ouesso (Est-Cameroun). Diplome d'Etudes approfondies. Univ. Douala, Cameroun.

[51] Kimpouni, V., Mbou, P., Gakosso, G. and Motom, M. (2013) Biodiversité floristique du sous-bois et régénération naturelle de la forêt de la Patte d'Oie de Brazzaville, Congo. International Journal of Biological and Chemical Sciences, 7, 1255-1270. https://doi.org/10.4314/ijbcs.v7i3.31

[52] Kimpouni, V., Lenga-Sacadura, M.-Y., Mamboueni, J.C. and Nsika Mikoko, E. (2018) Phytodiversité et pharmacopée traditionnelle de la communauté Kaamba de Madingou (Bouenza-Congo). European Scientific Journal, 14, 191-220. https://doi.org/10.19044/esj.2018.v14n3p191

[53] Kimpouni, V., Mamboueni, J.C., Mboussy Tsoungould, F.G. and Nsika Mikoko, E. (2019) Ethnobotanical and Phytotherapeutic Study from Kouni Community of the Sub-Prefecture of Kayes (Bouenza-Congo). Heliyon, 5, e02007. https://doi.org/10.1016/j.heliyon.2019.e02007

[54] Kimpouni, V., Apani, E. and Motom, M. (2012) Caractéristiques écologiques et composition de la flore ligneuse de la région de Mindouli (Congo). Journal de Botanique, Société Botanique de France, 57, 37-47.

[55] Kimpouni, V. (2008) Premières données sur la diversité floristique de la forêt d'Aubeville (Congo-Brazzaville). Systematics and Geography of Plants, 78, 47-62.

[56] Kimpouni, V. and Motom, M. (2012) Empirisme et exploitation traditionnelle de la flore par les populations riveraines du lac Cayo (Congo-Brazzaville). Annales de 
P Université Marien N gouabi, 12-13, 83-100.

[57] Baraloto, C. (2003) Régénération forestière naturelle: De la graine à la jeune tige. Revue Forestière Française (numéro spécial), 55, 179-187. https://doi.org/10.4267/2042/5770

[58] Pascal, J.-P. (2003) Notions sur les structures et dynamiques des forêts tropicales humides. Revue Forestière Française (numéro special), 55, 118-142. https://doi.org/10.4267/2042/5765

[59] Janzen, D.H. (1970) Herbivores and the Number of Tree Species in Tropical Forests. The American Naturalist, 104, 501-528. https://doi.org/10.1086/282687

[60] Ashton, P.S., Guillaumet, J.-L. and Lawton, R.M. (1983) La forêt naturelle: Biologie, régénération et croissance des arbres. In: Fournier, F. and Sasson, A., Ecosystèmes forestiers tropicaux d'Afrique, ORSTOM/UNESCO, Paris, 162-197.

[61] Frontier, S., Pichod-Viale, D., Leprêtre, A., Davoult D. and Luczak, C. (2008) Ecosystèmes: Structure, fonctionnement, évolution. Dunod, 4th Edition, Paris.

[62] Peters, C.M. (1997) Exploitation soutenue des produits forestiers autre que le bois en forêt Tropicale humide: Manuel d'initiation écologique. BSP, Washington DC.

[63] Ngansop, T.M. (2013) Potentiel de régénération naturelle de quelques espèces de Produits forestiers Non Ligneux majeurs de la périphérie Nord du parc national de Boumba-Bek, Sud-Est Cameroun. Mémoire de Master, Université de Yaoundé I.

[64] Ngom, D., Fall, T., Sarr, O., Diatta, S. and Akpo, L.E. (2013) Caractéristiques écologiques du peuplement ligneux de la réserve de biosphère du Ferlo (Nord Sénégal). Journal of Applied Biosciences, 65, 5008-5023. http://www.m.elewa.org https://doi.org/10.4314/jab.v65i0.89644

[65] Ngodo Melingui, J.B., Angoni, H., Claude, P.A. and Kono, L. (2017) Potentiel de régénération naturelle de quelques Produits Forestiers Non Ligneux prioritaires dans le bassin de production d'Akom II (Sud Cameroun). World Wide Journal of Multidisciplinary Research and Development, 4, 214-224. http://www.wwjmrd.com

[66] Traoré, S.A. (1997) Analyse de la flore et de la végétation de la zone de Simenti (Parc National du Niokolo Koba), Sénégal oriental. Thèse de $3^{\mathrm{e}}$ cycle. FST/UCAD (Sénégal).

[67] Puig, H., Forget P.-M. and Sist, P. (1989) Dissémination et régénération de quelques arbres en forêt tropicale guyanaise. Bulletin de la Société Botanique de France (Actualités Botaniques), 136, 119-131. https://doi.org/10.1080/01811789.1989.10826964

[68] Lubini, A. (1997) La végétation de la réserve de la biosphère de Luki. Opera Botanica Belgica, Bruxelles.

[69] Bischoff, N. (1987) Sylviculture en montagne. Guide pour la création et le traitement des forêts de montagne. Office fédéral des forêts et de la protection du paysage, Berne.

[70] Dupuy, J.M. and Chazdon, R.L. (2006) Effects of Vegetation Cover on Seedling and Sapling Dynamics in Secondary Tropical Wet Forests in Costa Rica. Journal of Tropical Ecology, 22, 65-76. https://doi.org/10.1017/S0266467405002890

[71] Yongo, O.D., Kassi, N’dja, J., Tiebre, M.S. and de Foucault, B. (2013) Régénération naturelle des espèces ligneuses dans la forêt de Ngotto (République Centrafricaine). Agronomie Africaine, 25, 105-111.

[72] Connel, J.H. (1971) On the Role of Natural Enemies in Preventing Competitive Exclusion in Some Marine Animals and in Forest Tree. In: den Boer, P.J. and Gradwell, G., Éds., Dynamics of Populations, Pudoc, Wageningen, 298-312. 
[73] Mpassi, P. (2007) Contribution à l'inventaire floristique et ethnobotanique des plantes utiles de Kimbédi. Mémoire CAPES, ENS, UMNG, Brazzaville.

[74] Guedje, N.M. and Fankap, R. (2001) Utilisations traditionnelles de Garcinia lucida et Garcinia kola (Clusiaceae) au Cameroun. Systematics and Geography of Plants, 71, 747-758. https://doi.org/10.2307/3668714

[75] Shackleton, S., Chinyimba, A., Hebinck, P., Shackleton, C. and Kaoma, H. (2015) Multiple Benefits and Values of Trees in Urban Landscapes in Two Towns in Northern South Africa. Landscape and Urban Planning, 136, 76-86. https://doi.org/10.1016/j.landurbplan.2014.12.004

[76] Seidler, T.G. and Plotkin, J.B. (2006) Seed Dispersal and Spatial Pattern in Tropical Trees. PLoS Biology, 4, e344. https://doi.org/10.1371/journal.pbio.0040344

[77] Sádlo, J., Chytrý, M., Pergl, J. and Pyšek, P. (2018) Plant Dispersal Strategies: A New Classification Based on the Multiple Dispersal Modes of Individual Species. Preslia, 90, 1-22. https://doi.org/10.23855/preslia.2018.001

[78] Quinn, J.F. and Dunham, A.E. (1983) On Hypothesis Testing in Ecology and Evolution. American Naturalist, 122, 602-617. https://doi.org/10.1086/284161

[79] Hubbell, S.P., Foster, S.R.B., O’Brien, T., Harms, K.E., Condit, R., Wechsler, B., Wright, S.J. and Loo de Lao, S. (1999) Light-Gap Disturbances, Recruitment Limitation and Tree Diversity in a Neotropical Forest. Science, 283, 554-557. https://doi.org/10.1126/science.283.5401.554

[80] Condit, R., Ashton, P.S., Baker, P., Bunyavejchewin, S., Gunatilleke, S., Gunatilleke, N., Hubbell, S.P., Foster, R.B., Itoh, A., LaFrankie, J.V., Lee, H.S., Losos, E., Manokaran, N., Sukumar, R. and Yamakura, T. (2000) Spatial Patterns in the Distribution of Common and Rare Tropical Tree Species: A Test from Large Plots in Six Different Forests. Science, 288, 1414-1418. https://doi.org/10.1126/science.288.5470.1414

[81] Pyke, C.R., Condit, R., Aguilar, S. and Lao, S. (2001) Floristic Composition across a Climatic Gradient in a Neotropical Low-Land Forest. Journal of Vegetation Science, 12, 553-566. https://doi.org/10.2307/3237007

[82] Flores, O. (2005) Déterminisme de la régénération chez quinze espèces d'arbres tropicaux en forêt guyanaise: Les effets de l'environnement et de la limitation par la dispersion. Thèse. Université de Montpellier II.

[83] Habiyaremye, F.X. (1993) Analyse phytosociologique des forêts primaires de la crête Zaïre-Nil au Rwanda. Belgian Journal of Botany, 126, 100-134.

[84] Schnitzer, S.A. and Carson, W.P. (2001) Treefall Gaps and the Maintenance of Species Diversity in a Tropical Forest. Ecology, 82, 913-919. https://doi.org/10.1890/0012-9658(2001)082[0913:TGATMO]2.0.CO;2

[85] Puerta-Piñero, C., Muller-Landau, H.C., Calderón, O. and Wright, S.J. (2013) Seed Arrival in Tropical Forest Treefall Gaps. Ecology, 94, 1552-1562.

https://doi.org/10.1890/12-1012.1

[86] Bagchi, R., Henrys, P.A., Brown, P.E., Burslem, D.F.R.P., Diggle, P., Gunatilleke, C.V.S., Gunatilleke, I.A.U.N., Kassim, A.R., Law, R., Noor, S. and Valencia, R.L. (2011) Spatial Patterns Reveal Negative Density Dependence and Habitat Associations in Tropical Trees. Ecology, 92, 1723-1729. https://doi.org/10.1890/11-0335.1 